\title{
Antimicrobial Effect of 2-Phenylethynyl-Butyltellurium in Escherichia coli and Its Association with Oxidative Stress
}

\author{
Franciane Cabral Pinheiro ${ }^{1}$, Vandreza Cardoso Bortolotto ${ }^{1}$, Stífani Machado Araujo ${ }^{1}$, Márcia Rósula Poetini ${ }^{1}$, \\ Carla Pohl Sehn ${ }^{1}$, José S. S. Neto ${ }^{2}$, Gilson Zeni ${ }^{2}$, and Marina Prigol ${ }^{1 *}$ \\ ${ }^{1}$ Laboratório de Avaliações Farmacológicas e Toxicológicas aplicadas às Moléculas Bioativas - Unipampa, Universidade Federal do Pampa - \\ Campus Itaqui, Itaqui, RS, 97650-000, Brazil \\ ${ }^{2}$ Laboratório de Sintese, Reatividade e Avaliação Farmacológica e Toxicológica de Organocalcogênios, Centro de Ciências Naturais e Exatas, \\ Universidade Federal de Santa Maria, Santa Maria, CEP 97105-900, RS, Brazil
}

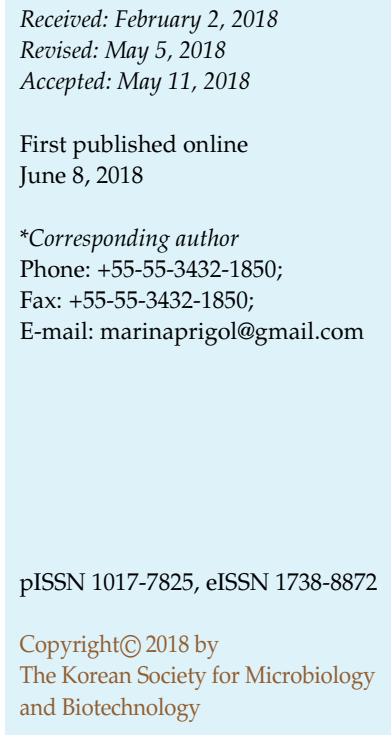

This study aimed to evaluate the antimicrobial activity of 2-phenylethynyl-butyltellurium (PEBT) in Escherichia coli and the relation to its pro-oxidant effect. For this, we carried out the disk diffusion test, minimum inhibitory concentration (MIC) assay, and survival curve analysis. We also measured the level of extracellular reactive oxygen species (ROS), activity of the antioxidant enzymes superoxide dismutase (SOD) and catalase (CAT), and level of nonprotein thiols (NPSH). PEBT at 1.28 and $0.128 \mathrm{mg} /$ disk exhibited antimicrobial capability in the disk diffusion test, with an MIC value of $1.92 \mathrm{mg} / \mathrm{ml}$, whereas PEBT at 0.96, 1.92, and $3.84 \mathrm{mg} / \mathrm{ml}$ inhibited bacterial growth after a 9-h exposure. PEBT at 3.84, 1.92, and $0.96 \mathrm{mg} / \mathrm{ml}$ increased extracellular ROS production, decreased the intracellular NPSH level, and reduced the SOD and CAT activities. Glutathione or ascorbic acid in the medium protected the bacterial cells from the antimicrobial effect of PEBT. In conclusion, PEBT exhibited antimicrobial activity against $E$. coli, involving the generation of ROS, oxidation of NPSH, and reduction of the antioxidant defenses in the bacterial cells.

Keywords: Antibacterial, tellurium, oxidative stress, pro-oxidant activity, thiol groups

\section{Introduction}

The emergence, propagation, accumulation, and maintenance of antimicrobial-resistant pathogenic bacteria have become a health concern in human and veterinary medicine worldwide [1]. Antibiotic resistance is one of the main causes of the difficulty in curing infectious diseases [2]. The abusive and indiscriminate use of antimicrobial drugs over the years is the main factor responsible for the appearance of antibacterial resistance [3]. This imposes severe limitations on therapeutic options, implying a threat to public health [4].

Pathogenic strains of Escherichia coli, a gram-negative rod-shaped bacterium found as a normal flora in the gastrointestinal tract of animals and humans, have emerged by the acquisition of virulence factors through transposons, plasmids, bacteriophage, and/or pathogenicity islands [5].
The level of antimicrobial resistance in E. coli is a useful indicator of the level of resistance expected in pathogenic bacteria. Antimicrobial-resistant bacteria and antimicrobial resistance genes can be exchanged between the animal reservoir and the human reserve, as a consequence of direct contact with animals or their environment or indirect contact through the food chain [1]. Studies have shown the effect of oxidative stress on the antimicrobial activity of drugs, such as fluoroquinolones and ciprofloxacin, whose antimicrobial activities are affected by the production of reactive oxygen species (ROS) [6]. Additionally, norfloxacin, ampicillin, and kanamycin showed an ability to induce oxidative stress and cell death in E. coli [7]. We have previously described ciprofloxacin as one of several antibiotics that induce oxidative stress in bacteria [8].

Substances that affect the generation of ROS in bacterial cells have the capability to undergo redox cycling, resulting 
in the generation of superoxide anion $\left(\mathrm{O}_{2}^{-}\right)$and hydrogen peroxide $\left(\mathrm{H}_{2} \mathrm{O}_{2}\right)$. Moreover, the production of ROS in E. coli, including superoxide anion, hydrogen peroxide, and hydroxyl radicals, are mainly related to the activity of the respiratory chain [9], and the increase in ROS level causes oxidative stress and thiol oxidation. Thiol oxidation has multiple damaging effects on cellular macromolecules. Some of these thiols form a part of cellular proteins, such as the $\operatorname{OxyR}$ transcriptional regulator, which is transitorily activated by the formation of disulfide linkage under oxidative stress [10,11].

To cope with oxidative stress, microorganisms use various defense mechanisms involving complementary action in different pathways. These include the evolution of specific enzymes targeted against a particular adverse substance [12]. For example, three superoxide dismutases (SODs) (encoded by $\operatorname{sod} A, \operatorname{sod} B$, and $\operatorname{sod} C$ genes) and two catalases, hydroperoxidase I and II (encoded by katG and katE, respectively), have been described in E. coli [13].

Several studies showed that compounds derived from tellurium exhibit toxic effects against microorganisms. For example, oxyanion tellurite $\left(\mathrm{TeO}_{3}{ }^{2-}\right)$ is extremely toxic to most microorganisms, particularly gram-negative bacteria $[14,15]$. It has been suggested that tellurite toxicity is due to its strong oxidizing ability, which might interfere with many cellular enzymatic processes [16]. Bacteria turn black upon exposure to tellurite because of the deposition of elemental tellurium (Te) within the cell [17]. Studies on the biological effects of inorganic and organic tellurium compounds have led to various interesting and promising applications [18].

The pharmacological properties of organotellurium compounds have been the subject of many research studies [19-22]. A telluroacetylene compound, 2-phenylethynylbutyltellurium (PEBT), at a low concentration has shown pharmacological effects in animal models of neurotoxicity and memory [20-22]. In contrast, several studies have established the toxicity of organotellurium compounds, including PEBT, which is associated with the oxidation of thiol groups in bioactive molecules, inhibiting sulfhydryl enzymes ( $\delta$-aminolevulinate dehydratase and $\mathrm{Na}^{+} \mathrm{K}^{+}$ATPase), or even decreasing the glutathione (GSH) concentration [20, 21, 23-25].

Several studies have also shown the involvement of oxidative stress in the antimicrobial activity of drugs. Antibiotics, such as fluoroquinolones and ciprofloxacin, exert antibacterial activity by inducing the generation of ROS [6]. In addition, it has been reported that the non-enzymatic antioxidant GSH exhibits a protective effect against

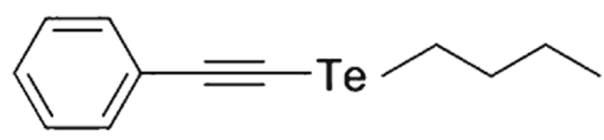

Fig. 1. Chemical structure of 2-phenylethynyl butyltellurium.

ciprofloxacin-induced ROS production in microorganisms [4]. Based on the above considerations, the present study aimed to verify the antimicrobial activity of PEBT in E. coli and examine the relation between its antimicrobial action and its pro-oxidant effect.

\section{Materials and Methods}

\section{Chemicals}

The compound PEBT (Fig. 1) was prepared according to a previous method [26]. Analysis of the ${ }^{1} \mathrm{H}$ NMR and ${ }^{13} \mathrm{C}$ NMR spectra showed that the synthesized PEBT exhibited analytical and spectroscopic data consistent with its designed structure. All other chemicals were of analytical grade and were purchased from standard commercial suppliers.

\section{Bacterium and Growth Conditions}

Escherichia coli (CCBH 17961) was obtained from the Oswaldo Cruz Foundation-FIOCRUZ (Brazil). The colonies were kept frozen in $10 \%$ glycerol until use. For each experiment, the colonies were transferred to nutrient broth and incubated for $24 \mathrm{~h}$ at $37^{\circ} \mathrm{C}$.

\section{Antimicrobial Activity}

Disk diffusion method. The disk diffusion method of antimicrobial resistance assay was carried out according to a previous method [27] with modifications. Isolates were cultivated in nutrient broth at $36^{\circ} \mathrm{C}$ and adjusted in a series of $0.85 \%$ saline solution at $0.5 \mathrm{McFarland}$ scale. The culture was subsequently spread on a plate containing Mueller-Hinton Agar (MHA). Paper disks of $\pm 6 \mathrm{~mm}$ in diameter (Laborclin, Ltda, Brazil) were soaked with $10 \mu \mathrm{l}$ of PEBT at concentrations of $1.28,0.128,0.0128$, and $0.00128 \mathrm{mg} /$ disk diluted in dimethyl sulfoxide (DMSO) and were placed on the seeded plates. The plates were incubated at $37^{\circ} \mathrm{C}$ for $24 \mathrm{~h}$. The halo formed was measured in centimeters from one extremity to the other. Paper disks soaked with DMSO (10 $\mu \mathrm{l})$ were used as a negative control. Each experiment was performed in triplicate.

Effects of antioxidants in the disk diffusion method. To examine the relation between the pro-oxidant and antimicrobial activities of PEBT, we performed the agar disk diffusion method using the antioxidants GSH and ascorbic acid (AA). E. coli was subcultured in nutrient agar and incubated at $37^{\circ} \mathrm{C}$ for $24 \mathrm{~h}$ to prepare the inoculums. The inoculum was dissolved in a series of sterile saline solution to a final concentration of approximately $1.5 \times 10^{8} \mathrm{CFU} / \mathrm{ml}$ adjusted at $0.5 \mathrm{McF}$ arland scale. MHA with or without $10 \mathrm{mM}$ solutions of GSH or AA was poured into sterilized 
petri dishes, where the inoculum was subsequently spread on. The 6-mm paper disks were soaked with $10 \mu \mathrm{l}$ of PEBT at concentrations of $1.28,0.128,0.0128$, and $0.00128 \mathrm{mg}$ dissolved in DMSO and were placed on the seeded plates. The plates were incubated at $37^{\circ} \mathrm{C}$ for $24 \mathrm{~h}$. The inhibition of the bacterial growth was determined by measuring the inhibition zone around the disks by a digital caliper. DMSO was used as a negative control. The method above was performed according to previous studies $[28,29]$ with modifications. Each experiment was performed in triplicate.

Broth macrodilution assay for minimum inhibitory concentration (MIC). The MIC of PEBT was determined by the broth macrodilution method according to the CLSI [27]. Seventeen micrograms of a standard bacterial inoculum of $5 \times 10^{5}$ colony forming units $(\mathrm{CFU}) / \mathrm{ml}$ was diluted serially in various concentrations of PEBT $(3.84,1.92,0.96,0.48,0.24,0.12,0.06$, and $0.030 \mathrm{mg} / \mathrm{ml}$ ) dissolved in DMSO, and the inoculum was incubated for $24 \mathrm{~h}$ at $36^{\circ} \mathrm{C}$. The MIC was defined as the lowest concentration of compound that completely inhibited visible growth. The experiment was performed in triplicate.

Kill-time curve assay. The kill-time curve assay method [30] was used to investigate the bactericidal effects of PEBT against E. coli at $0.5 \mathrm{MIC}, \mathrm{MIC}$, and 2 MIC. Tests were performed in triplicate at $37^{\circ} \mathrm{C}$. At the predetermined time points $(0,3,6,9,12$, and $24 \mathrm{~h}), 15 \mu \mathrm{l}$ of sample was removed from each test suspension, diluted in sterile saline $0.9 \%$, and plated on MHA plates for colony count determination. Data from triplicate runs were averaged and plotted as $\log \mathrm{CFU} / \mathrm{ml}$ versus time (h) for each time point.

\section{Extracellular Reactive Oxygen Species Assay}

E. coli was cultured in nutrient agar for $24 \mathrm{~h}$ at $37^{\circ} \mathrm{C}$ and suspended in sterile $0.9 \%$ saline, $\mathrm{pH} 7.4$. Its absorbance was adjusted to 0.8 at $\mathrm{OD}_{600}$. Subsequently, $67 \mu \mathrm{l}$ of E. coli was incubated with $10 \mu \mathrm{l}$ of $2^{\prime}, 7^{\prime}$-dichlorofluorescein diacetate (DCHF-DA; $10 \mathrm{nM}$ ) and PEBT at $0.96,1.92$, and $3.84 \mathrm{mg} / \mathrm{ml}$ (corresponding to $0.5 \mathrm{MIC}$, MIC, and 2 MIC, respectively). DCF fluorescence intensity emission was recorded at $520 \mathrm{~nm}$ excitation (with $488 \mathrm{~nm}$ emission) for $30 \mathrm{~min}$ for the detection of ROS in E. coli. The ROS level was expressed as units of fluorescence. The method described above was performed according to a previous study [31] with modifications.

\section{Incubation and Preparation of Lysates}

Bacterial cells $(50 \mathrm{ml})$ harvested from nutrient broth were centrifuged at 2,822.4 $\times g$ for $10 \mathrm{~min}$. The supernatant was removed, whereas the pellet was weighed, transferred to microtubes, and resuspended in $1 \mathrm{ml}$ of $0.1 \mathrm{mM}$ sodium phosphate buffer. The suspension was incubated for $30 \mathrm{~min}$ at $37^{\circ} \mathrm{C}$ in the presence of PEBT at $0.96,1.92$, or $3.84 \mathrm{mg} / \mathrm{ml}$ (corresponding to $0.5 \mathrm{MIC}$, MIC, and $2 \mathrm{MIC}$, respectively), or DMSO (control group). Afterwards, $0.9 \mathrm{~g}$ of glass beads was added to the microtubes, which were then mixed 6 times by a vortexer for $5 \mathrm{~min}$ each time and incubated for $2 \mathrm{~min}$ in an ice bath to complete a 30-min cycle [32]. Debris was removed from the suspension by centrifugation at 2,822.4 $\times g$ for $10 \mathrm{~min}$, after which the supernatant was collected for biochemical assays.

\section{Non-Protein Thiol Levels}

The levels of intracellular non-protein thiols (NPSHs) in E. coli were estimated using spectrophotometry according to a previous method [33] with adaptations. To prepare the sample, $200 \mu \mathrm{l}$ of supernatant was added to $200 \mu \mathrm{l}$ of $10 \%$ TCA. The mixture was vortexed for $1 \mathrm{~min}$ and centrifuged at $705.6 \times g$ for $10 \mathrm{~min}$. To $50 \mu \mathrm{l}$ of supernatant, $750 \mu \mathrm{l}$ of $1 \mathrm{M}$ potassium phosphate buffer (TFK) and $50 \mu \mathrm{l}$ of $10 \mathrm{mM}$ 5,5'-dithiobis(2-nitrobenzoic acid) were added. The absorbance was measured at $412 \mathrm{~nm}$ immediately after the addition of the reagents.

\section{Superoxide Dismutase Activity}

The activity of SOD was determined at $406 \mathrm{~nm}$ as the inhibition of quercetin oxidation in a reaction medium containing $30 \mathrm{mM}$ Tris-HCl buffer (pH 9.0), 0.3 mM EDTA, $0.8 \mathrm{mM}$ TEMED, $14 \mu \mathrm{M}$ quercetin, and $30 \mu \mathrm{l}$ of supernatant in a final volume of $2 \mathrm{ml}$. One unit of SOD activity was defined as the amount of supernatant protein that inhibited the maximum rate of quercetin oxidation by $50 \%$ [34].

\section{Catalase (CAT) Activity}

CAT activity was measured in accordance with a published method [35]. A solution was prepared using $0.25 \mathrm{M}$ potassium phosphate buffer, $2.5 \mathrm{mM}$ EDTA ( $\mathrm{pH} 7.0$ ), $30 \% \mathrm{H}_{2} \mathrm{O}_{2}$, and aqueous Triton X-100. For the test, $2 \mathrm{ml}$ of the prepared solution was added to $60 \mu \mathrm{l}$ of supernatant. The absorbance was monitored at $240 \mathrm{~nm}$ for $1 \mathrm{~min}$.

\section{Protein Concentration}

The protein concentration was determined by the Coomassie brilliant blue G-250 dye-binding method using bovine serum albumin as a standard [36].

\section{Statistical Analysis}

The data were analyzed using Prism 5 (GraphPad) software. Comparisons between the experimental and control groups were performed by one-way analysis of variance (ANOVA), followed by the Newman-Keuls post-hoc test. Data are expressed as the mean \pm SD. Probability values less than $0.05(p<0.05)$ were considered statistically significant.

\section{Results}

PEBT Caused Inhibition of $E$. coli Growth and the Presence of GSH and AA Blocked the Antimicrobial Effect of PEBT

In the present study, E. coli was sensitive to PEBT at the concentrations of $1.28-0.128 \mathrm{mg} /$ disk in a dose-dependent 
Table 1. Effect of glutathione (GSH) or ascorbic acid (AA) on 2phenylethynyl-butyltellurium (PEBT) inhibition of Escherichia coli growth.

\begin{tabular}{|c|c|c|c|}
\hline \multirow[t]{2}{*}{ PEBT (mg/disk) } & \multicolumn{3}{|c|}{ Diameter of the inhibition zone $(\mathrm{nm})$} \\
\hline & Medium & Medium + GSH & Medium + AA \\
\hline 0 & & & \\
\hline 0.00128 & & & \\
\hline 0.0128 & & & \\
\hline 0.128 & $1.067 \pm 0.3055^{*}$ & & \\
\hline 1.28 & $1.267 \pm 0.3055^{*}$ & & \\
\hline
\end{tabular}

Data are reported as the mean \pm SD and were analyzed using one-way ANOVA, followed by the Newman-Keuls test. *Numerical values are significantly different from the values of the corresponding control $(p<0.05)$.

manner. In contrast, it showed no sensitivity to PEBT at 0.0128 and $0.00128 \mathrm{mg} /$ disk, as shown in Table 1 .

The presence of $10 \mathrm{mM}$ GSH or AA in the growth medium lowered the susceptibility of E. coli to PEBT ( $p<$ $0.05)$, as shown in Table 1 . The presence of AA in the culture medium blocked the antimicrobial effect of 1.28 and $0.128 \mathrm{mg} /$ disk PEBT, indicated by the significantly reduced inhibition zone compared with that without AA. The antioxidant GSH also decreased the antimicrobial effect of 1.28 and $0.128 \mathrm{mg} /$ disk PEBT.

\section{Minimum Inhibitory Concentrations}

The MIC of PEBT as an antimicrobial agent was $1.92 \mathrm{mg} / \mathrm{ml}$, as shown in Table 2. This MIC value was used as the PEBT concentration in the subsequent examination of antioxidant enzyme activity, NPSH levels, and ROS generation.

\section{Kill-Time Curve}

E. coli was incubated for $24 \mathrm{~h}$ in the presence of PEBT at concentrations relative to its MIC, namely $0.5 \mathrm{MIC}, \mathrm{MIC}$, and 2MIC, which corresponded to $0.96,1.92$, and $3.68 \mathrm{mg} / \mathrm{ml}$, respectively, in order to determine the time-response effect of the compound. Following incubation, no viable cells of E. coli were observed (Fig. 2) in the PEBT-treated cultures.

\section{PEBT Exposure Increases Reactive Oxygen Species Production}

The ROS level was used to monitor the formation of extracellular ROS in E. coli treated with various concentrations

Table 2. Minimum inhibitory concentration (MIC) of 2phenylethynyl-butyltellurium in Escherichia coli.

\begin{tabular}{cccc}
\hline & $0.5 \mathrm{MIC}(\mathrm{mg} / \mathrm{ml})$ & $\mathrm{MIC}(\mathrm{mg} / \mathrm{ml})$ & $2 \mathrm{MIC}(\mathrm{mg} / \mathrm{ml})$ \\
\hline Escherichia coli & 0.96 & 1.92 & 3.68 \\
\hline
\end{tabular}

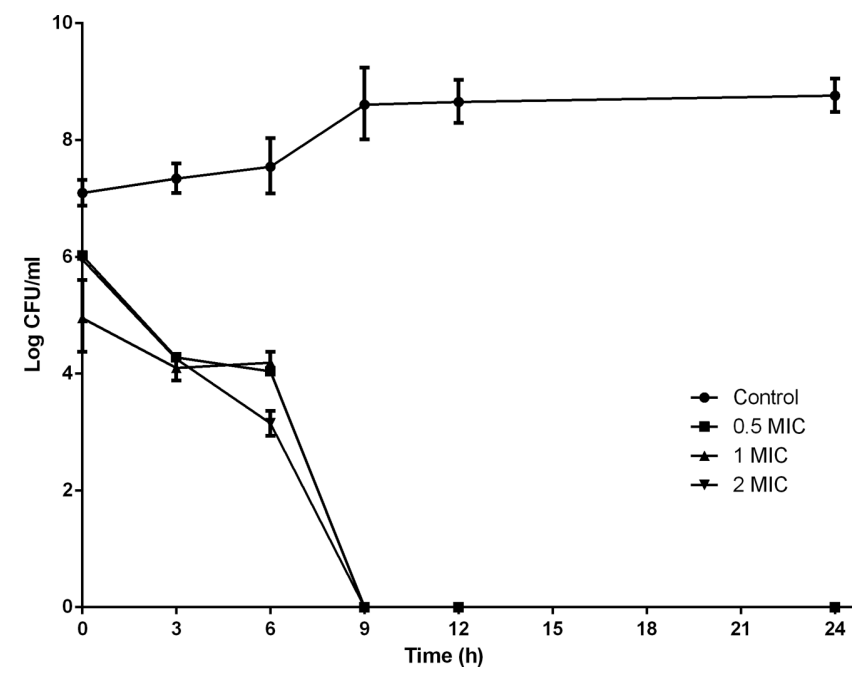

Fig. 2. Time-course of different concentrations of PEBT after exposure to E. coli $0.5 \mathrm{MIC}$ (0.5-fold minimum inhibitory concentration), MIC (1-fold minimum inhibitory concentration), and 2 MIC (2-fold minimum inhibitory concentration).

Data are reported as the mean $\pm \mathrm{SD}$ and were analyzed by one-way ANOVA, followed by the Newman-Keuls test when appropriate.

of PEBT $(0.96,1.92$, and $3.68 \mathrm{mg} / \mathrm{ml})$. PEBT at all tested concentrations had pro-oxidant activity in E. coli, as indicated by the increase in ROS level compared with the control group (Fig. 3). This result suggested that the pro-oxidative effects of PEBT are mediated, at least in part, by an increase in extracellular ROS concentration.

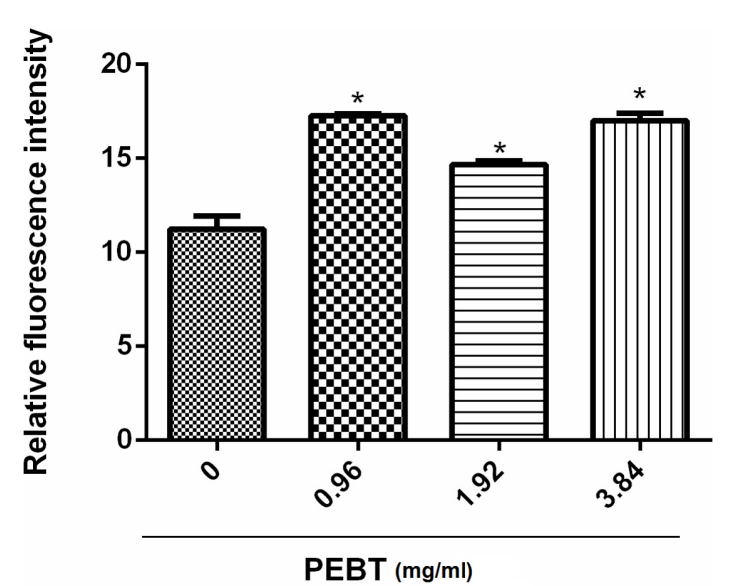

Fig. 3. Total extracellular reactive oxygen species in E. coli exposed to PEBT.

Data are reported as the mean \pm SD and were analyzed by one-way ANOVA, followed by the Newman-Keuls test when appropriate. ${ }^{*}$ Numerical values are significantly different from the values of the corresponding control $(p<0.05)$. 


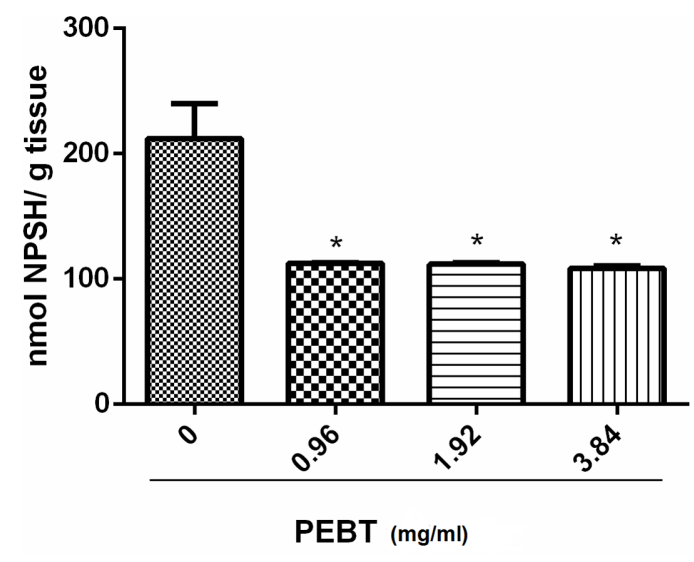

Fig. 4. Levels of non-protein thiols (NPSHs) in E. coli exposed to PEBT.

Data are reported as the mean \pm SD and were analyzed by one-way ANOVA, followed by the Newman-Keuls test when appropriate. *Numerical values are significantly different from the values of the corresponding control $(p<0.05)$.

\section{PEBT Exposure Decreased Non-Protein Thiol Levels}

NPSH levels were measured in E. coli exposed to PEBT at $0.96,1.92$, and $3.68 \mathrm{mg} / \mathrm{ml}$. Significant reduction in the NPSH levels was observed in the cultures exposed to PEBT at all concentrations (Fig. 4) compared with the control.

PEBT Exposure Decreased Superoxide Dismutase and Catalase Activities

To determine the effect of PEBT on the ROS-responsive enzymatic behavior of $E$. coli, the activities of CAT and SOD were examined in E. coli cultures treated with PEBT at $0.96,1.92$, and $3.68 \mathrm{mg} / \mathrm{ml}$. PEBT treatment significantly decreased the SOD and CAT activities compared with control, as shown in Figs. 5A and 5B, respectively.

\section{Discussion}

Tellurium compounds have been proven to exert toxic effects in most microorganisms, especially in gramnegative bacteria $[14,15]$. In the present study, we verified the antimicrobial activity of the telluroacetylene compound PEBT against E. coli. Our results indicated that the prooxidant effects of PEBT were a possible mechanism behind its antimicrobial activity. It was suggested that PEBT acted by inducing the generation of ROS, oxidation of thiol groups, and reduction of SOD and CAT activities, which led to cellular damage and cell death.

PEBT was positive for antimicrobial activity, as indicated by its consistent inhibitory effect against the growth of
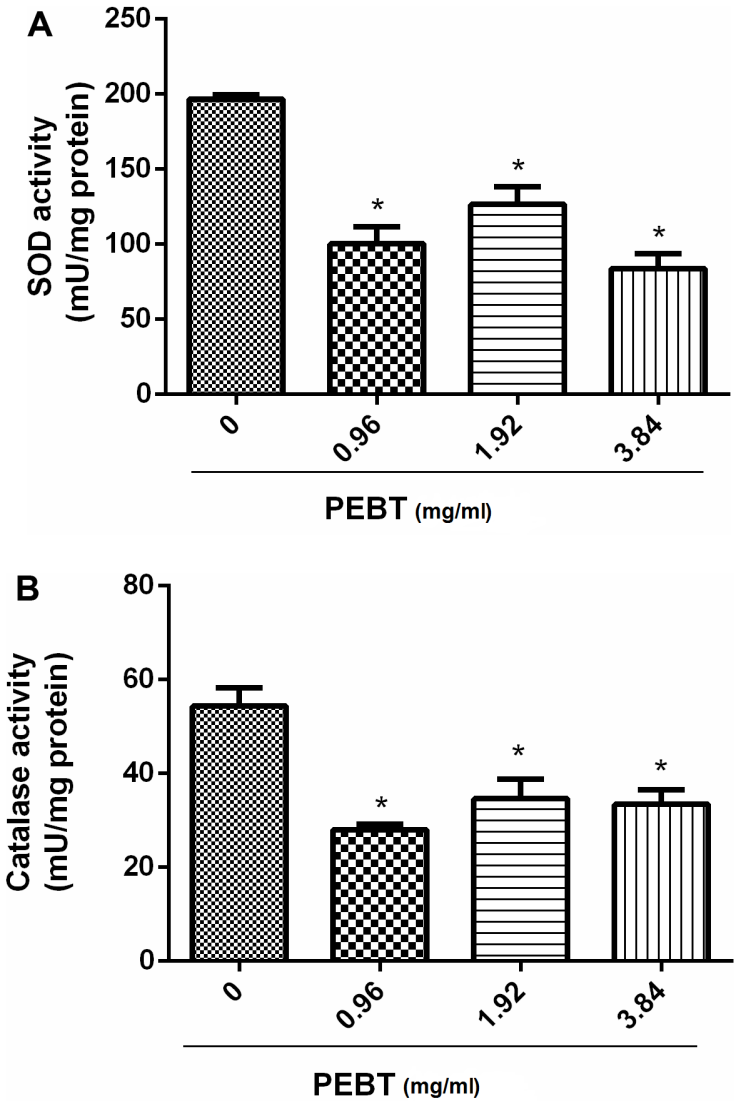

Fig. 5. Activity of superoxide dismutase (A) and catalase (B) in E. coli exposed to PEBT.

Data are reported as the mean \pm SD and were analyzed by one-way ANOVA, followed by the Newman-Keuls test when appropriate. ${ }^{*}$ Numerical values are significantly different from the values of the corresponding control $(p<0.05)$.

E. coli in the disk diffusion, MIC, and survival curve tests. In the disk diffusion test, PEBT at 0.128 and $1.28 \mathrm{mg} /$ disk successfully produced zones of inhibition, which showed the susceptibility of $E$. coli to this compound. This result was of high importance since E. coli and other bacterial species have become increasingly resistant to antibiotics, which are associated with $95 \%$ of the cases of infection in healthcare professionals. Studies have shown that other tellurium compounds exhibit antibacterial activity against gram-positive (Bacillus subtilis, Staphylococcus aureus) [37] and gram-negative bacteria (Escherichia coli, Pseudomonas aeruginosa, and Salmonella sp.) [14]. In the present study, PEBT at $1.92 \mathrm{mg} / \mathrm{ml}$ exerted bactericidal action against E. coli, whereas PEBT at $0.96,1.92$, and $3.84 \mathrm{mg} / \mathrm{ml}$ exerted bactericidal activity, as indicated by the significant reduction in viable cell count after $9 \mathrm{~h}$ of exposure. We 
propose that both the bactericidal and bacteriostatic actions of PEBT were dependent on its concentration and time of exposure.

The present study also observed an increase in the production of ROS in E. coli treated with PEBT at 0.96, 1.92, and $3.84 \mathrm{mg} / \mathrm{ml}$, which represented $0.5 \mathrm{MIC}$, MIC, and 2 MIC, respectively. It is well known that increased levels of ROS lead to damage to cellular components, including DNA as well as membrane lipids and proteins. In addition, we observed a decrease in NPSH level in E. coli exposed to PEBT. Taken together, these two results clearly showed the pro-oxidant effect of PEBT. Previous studies showed that PEBT catalytically oxidizes glutathione sulfhydryl groups of various proteins and enzymes [20-22]. This effect, which can lead to cellular toxicity, is potentially associated with the antimicrobial activity of PEBT observed in this study. In this context, other studies showed that E. coli exposed to tellurium compounds exhibited a decrease in ATP levels, an increase in ROS generation, carbonylation of proteins, and a decrease in cellular reduced-thiol content $[14,15,17$, $38,39]$. The oxidation of thiols is associated with cell toxicity and death $[17,23,24]$.

Previous studies have shown that E. coli can function efficiently in the presence of substances that alter $\mathrm{O}_{2}$ levels owing to the excellent activity of $\operatorname{SOD}[6,12,10]$. In fact, E. coli has three different $\mathrm{O}_{2}$-metabolizing SOD enzymes encoded by $\operatorname{sod} A, \operatorname{sod} B$, and $\operatorname{sod} C$ genes, as well as two catalases, hydroperoxidase I and II (encoded by kat $G$ and $k a t E$, respectively), which are involved in the detoxification of intracellular $\mathrm{H}_{2} \mathrm{O}_{2}[40,41]$. The various responses of SOD and CAT to oxidative stress suggest that oxidative stress is one of the most important aspects of chemical stress [42]. In the present study, the SOD and CAT activities were decreased in the presence of PEBT at various concentrations. In fact, the activity of these enzymes was associated with the elevated level of ROS. Previous studies have shown that SOD and CAT are key enzymes in the defense against oxidative stress [20,42,43]. In this contest, the decrease in antioxidant activity of SOD and CAT observed in the present study can lead to insufficient enzymatic responses, resulting in poor defense against oxidative stress and cell death.

To determine the relationship between the pro-oxidant activities and the antimicrobial effect of PEBT, we added GSH and AA, two well-known antioxidants, in the culture medium of E. coli. The presence of GSH or AA in the medium was effective in decreasing the diameter of PEBTinduced inhibition zone. It is well known that GSH removes oxygen radicals [44] and some studies showed that antioxidants such as GSH and AA protect mutants of E. coli against pro-oxidant compounds [4]. The results in the present study were consistent with other studies that reported the association between oxidative stress and the antimicrobial effect of ciprofloxacin [6, 44,47], norfloxacin, ampicillin, kanamycin A [7], and 2,2'-dithienyl diselenide [4].

In conclusion, the present study revealed that PEBT exhibited bactericidal and bacteriostatic actions against E. coli. Additionally, we confirmed that the pro-oxidant activity of PEBT is involved in the mechanism of its antimicrobial effect. PEBT oxidized the thiol groups of biomolecules, which consequently raised the levels of ROS and lowered the activities of SOD and CAT. These alterations led to a decrease in the decomposition of free radicals in E. coli, causing cellular damage and eventual cell death.

\section{Acknowledgments}

The authors gratefully acknowledge the financial support received from FAPERGS, CNPq (Universal 483529/2013-3) and UNIPAMPA.

\section{Conflict of Interest}

The authors have no financial conflicts of interest to declare.

\section{References}

1. Holvoet K, Sampers I, Callens B, Dewulf J, Uyttendaele M. 2013. Moderate prevalence of antimicrobial resistance in Escherichia coli isolates from lettuce, irrigation water, and soil. Appl. Environ. Microbiol. 79: 6677-6683.

2. Matuschek E, Brown DF, Kahlmeter G. 2014. Development of the EUCAST disk diffusion antimicrobial susceptibility testing method and its implementation in routine microbiology laboratories. Clin. Microbiol. Infect. 20: 255-266.

3. Andremont A. 2001. The future control of bacterial resistance to antimicrobial agents. Am. J. Infect. Control 29: 256-258.

4. Pesarico AP, Sartori G, dos Santos CFA, Neto JSS, Bortolotto V, Santos RCV, et al. 2013. 2,2-Dithienyl diselenide pro-oxidant activity accounts for antibacterial and antifungal activities. Microbiol. Res. 168: 563-568.

5. Oloketuyi SF, Khan F. 2017. Strategies for biofilm inhibition and virulence attenuation of foodborne pathogen-Escherichia coli O157:H7. Curr. Microbiol. 74: 1477-1489.

6. Albesa I, Becerra MC, Battan PC, Paez PL. 2004. Oxidative stress involved in the antibacterial action of different 
antibiotics. Biochem. Biophys. Res. Commun. 317: 605-609.

7. Choia H, Yanga Z, Weisshaar JC. 2015. Single-cell, real-time detection of oxidative stress induced in Escherichia coli by the antimicrobial peptide CM15. Proc. Natl. Acad. Sci. USA 112: 303-310.

8. Páez PL, Bazán CM, Bongiovanni ME, Toneatto J, Albesa I, Becerra MC, et al. 2013. Oxidative stress and antimicrobial activity of chromium(III) and ruthenium(II) complexes on Staphylococcus aureus and Escherichia coli. Biomed. Res. Int. 2013: 906912.

9. Semchyshyn H, Bagnyukova $T$, Storey KB, Lushchak V. 2005. Hydrogen peroxide increases the activities of soxRS regulon enzymes and the levels of oxidized proteins and lipids in Escherichia coli. Cell Biol. Int. Rep. 29: 898-902.

10. Chasteen TG, Fuentes DE, Tantaleán JC, Vásquez CC. 2009. Tellurite: history, oxidative stress, and molecular mechanisms of resistance. FEMS Microbiol. Rev. 33: 820-832.

11. Zhang Y, Meng D, Wang Z, Guo H, Wang Y, Wang X, et al. 2012. Oxidative stress response in atrazine-degrading bacteria exposed to atrazine. J. Hazard. Mater. 30: 434-438.

12. Aradská J, Smidák R, Turkovicová L, Turna J, Lubec G. 2013. Proteomic differences between tellurite-sensitive and tellurite-resistant E. coli. PLoS One 8: e78010.

13. Cabiscol E, Tamarit J, Ros J. 2000. Oxidative stress in bacteria and protein damage by reactive oxygen species. Int. Microbiol. 3: 3-8.

14. Vásquez WA, Lagunas MJ, Arenas FA, Pinto CA, Cornejo FA, Wansapura PT, et al. 2014. Tellurite reduction by Escherichia coli $\mathrm{NDH}-\mathrm{II}$ dehydrogenase results in superoxide production in membranes of toxicant-exposed cells. Biometals 27: 237-246.

15. Vásquez WA, Lagunas MJ, Cornejo FA, Pinto CA, Arenas FA, Vásquez CC. 2015. Tellurite-mediated damage to the Escherichia coli NDH-dehydrogenases and terminal oxidases in aerobic conditions. Arch. Biochem. Biophys. 566: 67-75.

16. Taylor DE. 1999. Bacterial tellurite resistance. Trends Microbiol. 7: 111-115.

17. Turner RJ, Weiner JH, Taylor DE. 1999. Tellurite-mediated thiol oxidation in Escherichia coli. J. Microbiol. 145: 2549-2557.

18. Cunha RLOR, Gouvea IE, Juliano L. 2009. A glimpse on biological activities of tellurium compounds. An. Acad. Bras Ciênc. 81: 393-407.

19. Ávila DS, Beque MC, Folmer V, Braga AL, Zeni G, Nogueira CW, et al. 2006. Diethyl 2-phenyl-2 tellurophenyl vinylphosphonate: an organotellurium compound with low toxicity. Toxicology 224: 100-107.

20. Quines CB, Rosa SG, Neto JS, Zeni G, Nogueira CW. 2013. Phenylethynyl-butyltellurium inhibits the sulfhydryl enzyme $\mathrm{Na}^{+}, \mathrm{K}^{+}$ATPase: an effect dependent on the tellurium atom. Biol. Trace Elem. Res. 155: 261-266.

21. Quines CB, Rocha JT, Pesarico AP, Neto, JS, Zeni G, Nogueira CW. 2015. Involvement of the serotonergic system in the anxiolytic-like effect of 2-phenylethynyl-butyltellurium in mice. Behav. Brain Res. 277: 221-227.
22. Souza AC, Luchese C, Neto JS, Nogueira CW. 2009. Antioxidant effect of a novel class of telluroacetilene compounds: studies in vitro and in vivo. Life Sci. J. 84: 351-357.

23. Puntel RL, Roos D, Seeger RL, Rocha JB. 2012. Organochalcogens inhibit mitochondrial complexes I and II in rat brain: possible implications for neurotoxicity. Neurotox. Res. 24: 109-118.

24. Puntel RL, Roos D, Seeger RL, Rocha JB. 2013. Mitrochondrial inhibition by different organochalcogens. Toxicol. In Vitro 27: 59-79.

25. Souza AC, Acker CI, Gai BM, Neto JS, Nogueira CW. 2012. 2-Phenylethynyl-butyltellurium improves memory in mice. Neurochem. Int. 60: 409-414.

26. Comasseto JV, Menezes PH, Stefani HA, Zeni G, Braga AL. 1996. Addition of hydrogen halides to acetylenic selenides. Synthesis of 1-halo-1-selenoalkenes. Tetrahedron 52: 9687-9702.

27. Clinical and Laboratory Standards Institute. 2009. Performance standards for antimicrobial susceptibility testing; nineteenth informational supplement. CLSI, Wayne, PA.

28. Politi ASF, Mello PCJ, Migliato FK, Neupomuceno ALA, Moreira DRR, Pietro CLRR. 2011. Antimicrobial, cytotoxic and antioxidant activities and determination of the total tannin content of bark extracts Endopleura uchi. Int. J. Mol. Sci. 12: 2757-2768.

29. Goswami M, Mangoli SH, Jawali N. 2006. Involvement of reactive oxygen species in the action of ciprofloxacin against Escherichia coli. Antimicrob. Agents Chemother. 50: 949-54.

30. Santos RC, dos Santos Alves CF, Scheneider T, Lopes LQ, Aurich C, Giongo JL, et al. 2012. Antimicrobial activity of Amazonian oils against Paenibacillus species. J. Invertebr. Pathol. 8: 109:265.

31. Socci DJ, Bjugstad KB, Jones HC, Pattisapu JV, Arendash GW. 1999. Evidence that oxidative stress is associated with the pathophysiology of inherited hydrocephalus in the H-Tx rat model. J. Neuropathol. Exp. Neurol. 155: 109-117.

32. Medeiros FO, Alves FG, Lisboa CR, Martins DR, Burkert CAV. 2008. Ondas ultrassônicas e pérolas de vidro: um novo método de extração de $\beta$-galactosidase para uso em laboratório. Quim. Nova 31: 336-339.

33. Ellman GL. 1959. Tissue sulfhydryl groups. Arch. Biochem. Biophys. 82: 70-77.

34. Kostyuk VA, Potapovich AI. 1989. Superoxide driven oxidation of quercetin and a simple sensitive assay for determination of superoxide dismutase. Biochem. Int. 19: 1117-1124.

35. Aebi H. 1984. Catalase in vitro. Methods Enzymol. 105: 121-126.

36. Bradford MM. 1976. A rapid and sensitive method for the quantitation of microgram quantities of protein utilizing the principle of protein-dye binding. Anal. Biochem. 72: 248-254.

37. Soni D, Gupta KP, Humar Y, Chandrashekharn TG. 2005. Antibacterial activity of some unsymmetrical diorganyltellurium (IV) dichlorides. Indian J. Biochem. Biophys. 42: 398-400.

38. Imlay JA. 2008. Cellular defenses against superoxide and 
hydrogen peroxide. Annu. Rev. Biochem. 77: 755-776.

39. Imlay JA. 2013. The molecular mechanisms and physiological consequences of oxidative stress: lessons from a model bacterium. Rev. Nat. Microbiol. 11: 443-454.

40. Keele BB, McCord JM, Fridovich I. 1970. Superoxide dismutase from Escherichia coli B: a new manganese-containing enzyme. J. Biol. Chem. 245: 6176-6181.

41. Loewen PC, Switala J, Triggs-Raine L. 1985. Catalase HPI and HPII in Escherichia coli are induced independently. Arch. Biochem. Biophys. 243: 144-149.

42. Lin X, Xu X, Yang C, Zhao Y, Feng Z, Dong Y. 2009. Activities of antioxidant enzymes in three bacteria exposed to bensulfuron-methyl. Ecotoxicol. Environ. Saf. 72: 1899-1904.

43. Lü Z, Sang L, Li Z, Min H. 2008. Catalase and superoxide dismutase activities in a Strenotrophomonas maltophilia WZ2 resistant to herbicide pollution. Ecotoxicol. Environ. Saf. 72: 136-143.

44. Goswami M, Mangoli SH, Jawali N. 2006. Involvement of reactive oxygen species in the action of ciprofloxacin against Escherichia coli. Antimicrob. Agents Chemother. 50: 949-954.

45. Becerra MC, Albesa I. 2002. Oxidative stress induced by ciprofloxacin in Staphylococcus aureus. Ccommunications 4: 1003-1007. 